\title{
Potent antitrypanosomal triterpenoid saponins from Mussaenda luteola
}

Shaymaa M. Mohamed ${ }^{\text {a,b }}$, Enaam Y. Bachkeet ${ }^{\mathrm{b}}$, Soad A. Bayoumi ${ }^{\mathrm{b}}$, Surendra Jain ${ }^{\text {a,c }}$, Stephen J. Cutler ${ }^{\text {a,c }}$, Babu L. Tekwani ${ }^{\text {a,c }}$, Samir A. Ross ${ }^{\text {a,c,* }}$

${ }^{a}$ National Center for Natural Products Research, The University of Mississippi, University, MS 38677, United states.

${ }^{b}$ Department of Pharmacognosy, Faculty of Pharmacy, Assiut University, Assiut, Egypt.

${ }^{c}$ Department of BioMolecular Sciences, School of Pharmacy, The University of Mississippi, University, MS38677, United states.

* Corresponding author. Tel.: +1-662-915-1031, fax: +1-662-915-7989

E-mail address: sross@olemiss.edu 


\section{ABSTRACT}

Five new triterpenoid saponins, heinsiagenin A 3- $O$ - $[\alpha$-L-rhamnopyranosyl- $(1 \rightarrow 2)-\beta$-Dglucopyranosyl-( $(1 \rightarrow 2)]$ - $\beta$-D-glucopyranoside $(\mathbf{1})$, heinsiagenin A 3- $O$-[ $\alpha$-L-rhamnopyranosyl$(1 \rightarrow 2)$ - $\beta$-D-glucopyranosyl-( $1 \rightarrow 2)]$-[ $\beta$-D-glucopyranosyl-(1 $\rightarrow 4)]-\beta$-D-glucopyranoside $(2), \quad 2 \alpha$ hydroxyheinsiagenin A 3- $O$-[ $\alpha$-L-rhamnopyranosyl-( $1 \rightarrow 2)$ - $\beta$-D-glucopyranosyl- $(1 \rightarrow 2)]-\beta$-Dglucopyranoside (3), $2 \alpha$-hydroxyheinsiagenin A $\quad 3-O$-[ $\beta$-D-glucopyranosyl- $(1 \rightarrow 2)]-[\beta$-Dglucopyranosyl-(1 $\rightarrow 4)]-\beta$-D-glucopyranoside $(4)$ and $N$-(2S, 3R, 4R-3-methyl-4-pentanolid-2-yl)18-hydroxylanosta-8 (9), 22E， 24E-trien-27-amide-3- $O$-[ $\alpha$-L-rhamnopyranosyl-(1 $\rightarrow 2)-\beta$-Dglucopyranosyl- $(1 \rightarrow 2)]$-[ $\beta$-D-glucopyranosyl-( $1 \rightarrow 4)]-\beta$-D-glucopyranoside $\quad(\mathbf{5})$ were isolated from the aerial parts of Mussaenda luteola Delile (Rubiaceae). Structural elucidation was based on the analysis of spectroscopic data (1D and 2D NMR) and HR-ESI-MS. Compound 1 showed potent antitrypanosomal activity with an $\mathrm{IC}_{50}$ value of $8.80 \mu \mathrm{M}$. Compounds 2-4 showed highly potent antitrypanosomal activity with $\mathrm{IC}_{50}$ values ranging between $(2.57-2.84 \mu \mathrm{M})$ and $\mathrm{IC}_{90}$ values ranging between $(3.36-4.35 \mu \mathrm{M})$, which are 5 fold greater than the positive control DFMO (IC50 and IC $_{90}$ values of 13.06 and $28.99 \mu \mathrm{M}$, respectively). Compounds $\mathbf{1}$ and $\mathbf{2}$ showed moderate affinity to $\mu$-opioid receptors with $\mathrm{K}_{\mathrm{i}}$ values of $9.936 \mu \mathrm{M}$ and $0.872 \mu \mathrm{M}$, respectively compared to a $\mathrm{K}_{\mathrm{i}}$ value of $1.958 \mathrm{nM}$ for the positive control, naloxone $\mathrm{HCl}$.

Keywords:

Mussaenda luteola

Rubiaceae

triterpenoid saponins

antitrypanosomal

$\mu$-opioid receptor binding 


\section{Introduction}

Mussaenda (Rubiaceae) is an important source of medicinal natural products. Mussaenda species are native to West Africa, the Indian sub-continent, South-East Asia, and Southern China [1]. There are more than 200 species of Mussaenda [1]. Some species have historically been used in Chinese and Fijian traditional medicine as a diuretic, antiphlogistic, antipyretic, abortifacient, expectorant and antimicrobial [1]. Non glycosidic iridoids like Mussaein, from M. pubesens, are cytotoxic [2]. This report is the first phytochemical and biological investigation on Mussaenda luteola Delile shrubs.

Several triterpenoid cycloartane saponins have been isolated from M. pubescens [3-5]. Most saponins possess a variety of bioactivities including cardiac, antifungal, hemolytic activities and the ability to affect metabolism and biosynthesis [6]. Mussaendoside F, isolated from $M$. pubescens, was considered as an antagonist of the M-Ach receptor. Additionally, it significantly promoted the proliferation of T-cells in mice in vitro [4]. In the continuation to search for new active metabolites, this paper reported the isolation and structure elucidation of five new saponins from M. luteola. Additionally, their antiprotozoal activities and cannabinoid, and opioid receptor binding affinities were evaluated.

Trypanosoma brucei brucei is a unicellular parasite transmitted by the bite of tsetse fly and is the causative agent of sleeping sickness in humans and related diseases in animals [7]. Current treatment of both African and American trypanosomiasis is unsatisfactory [8]. For the treatment of sleeping sickness only four drugs are available [9]. Suramin and pentamidine are effective against the early stages of $T . b$. rhodesiense and $T . b$. gambiense infections, respectively [10]. Melarsoprol is a trivalent arsenical agent and was introduced in 1949 for treating of late-stage sleeping sickness caused by T. brucei spp [10]. DFMO, a selective inhibitor of ornithine decarboxylase, is the only new drug for chemotherapy of sleeping sickness, which was first used in 1990 [10]. Thus, the identification of new agents with selective trypanocidal activity, that can serve as lead compounds for the development of future antitrypanosomal drugs, is of paramount importance. 


\section{Experimental}

\subsection{General procedures}

Optical rotations were measured with an Autopol IV automatic polarimeter. IR spectra were obtained using a Bruker Tensor 27 IR spectrometer. UV spectra were recorded on Cary-50 Bio spectrophotometer. The ${ }^{1} \mathrm{H},{ }^{13} \mathrm{C}$ and 2D NMR spectra were recorded on a Varian Mercury 400 MHz spectrometer at $400\left({ }^{1} \mathrm{H}\right)$ and $100\left({ }^{13} \mathrm{C}\right)$ using TMS as internal standard. The HR-ESI-MS were obtained using a Bruker BioApex-FTMS with electrospray ionization (ESI). Column chromatography (CC) was performed on silica gel 60 F254 (0.2 mm, Merck), Diaion HP-20, Sephadex ${ }^{\mathrm{TM}}$ LH-20 and MN-polyamide-SC-6.

\subsection{Plant material}

Aerial parts of Mussaenda luteola were collected from the El-Zohria Research Garden, Cairo, Egypt in May 2012. The plant material was identified by Professor Mo'men Mostafa Mahmoud, Professor of Taxonomy, Faculty of Science, Assiut University, Assiut, Egypt. A voucher specimen (No. 36) has been deposited at the herbarium of the Pharmacognosy Department, Faculty of Pharmacy, Assiut University, Egypt.

\subsection{Extraction and isolation}

The dried powdered plant material (600 g) was exhaustively extracted by maceration with $70 \%$ methanol $(4 \mathrm{~L} \times 3)$ at room temperature for three days. The combined extracts were evaporated under reduced pressure to afford a dry residue $(50 \mathrm{~g})$. Silica gel VLC was used for the initial fractionation of the methanolic extract eluted sequentially with $n$-hexane, EtOAc and $\mathrm{MeOH}$ to give three fractions (F1-F3). F3 (28.5 g) was subjected to Diaion-HP-20 CC and eluted with distilled water then methanol. The methanol subfraction (7.2 g) was subjected to MN-polyamide-SC-6 CC, which was eluted initially with water then gradient decreased polarities with $\mathrm{H}_{2} \mathrm{O}-\mathrm{MeOH}$ systems to give eight subfractions (Fr.1-8). Further purification for subfraction Fr.5 (652.6 mg), eluted by $\mathrm{H}_{2} \mathrm{O}-\mathrm{MeOH}$ (60:40), on silica gel (25 g) CC initially eluted with $\mathrm{CHCl}_{3}-\mathrm{MeOH}(90: 10)$ then $(85: 15)$ and $(80: 20)$ resulted in the isolation of compound 5 (6.8 mg). Subfraction Fr.6 (490.9 mg), eluted by $\mathrm{H}_{2} \mathrm{O}-\mathrm{MeOH}$ (1:1), was subjected to Sephadex LH-20 (50 g) CC [1(ID)× 80(L) cm], which was eluted with $\mathrm{MeOH}$ to give three subfractions Fr.6-A to Fr.6-C. Fr.6-B (305.6 mg) was subjected to silica gel (10 g) CC [1(ID)× 20(L) $\mathrm{cm}$ ], which was eluted initially with EtOAc-DCM-MeOH-H $2 \mathrm{O}(80: 40: 11: 2)$ to obtain subfractions (1-80) followed by EtOAc-DCM-MeOH-H $2 \mathrm{O}$ (15:8:4:1) to obtain subfractions (81- 
140) to afford compounds 3 (5.4 mg) and 4 (4.7 mg). Subfraction Fr.7 (207 mg), eluted by $\mathrm{H}_{2} \mathrm{O}-$ $\mathrm{MeOH}$ (40:60), was subjected to Sephadex LH-20 (25 g) CC [1(ID)× 40(L) cm], which was eluted with DCM-MeOH (1:1) to give three subfractions (Fr.7-A to Fr.7-C). Fr. 7A (118.5 mg) was subjected to silica gel $(8.0 \mathrm{~g})$ [1(ID) $\times 20(\mathrm{~L}) \mathrm{cm}] \mathrm{CC}$, which was eluted initially with $\mathrm{CHCl}_{3}$ followed by gradient $\mathrm{CHCl}_{3}-\mathrm{MeOH}$ systems $(95: 5,90: 10$ then 85:5) to afford compound 1 (11.0 $\mathrm{mg})$ and compound 2 (15.0 $\mathrm{mg})$.

Heinsiagenin $\quad$ A $\quad 3-O$ - $[\alpha$-L-rhamnopyranosyl- $(1 \rightarrow 2)-\beta$-D-glucopyranosyl- $(1 \rightarrow 2)]-\beta$-Dglucopyranoside (1). Yellowish white amorphous powder; $[\alpha]_{\mathrm{D}}{ }^{20}+18.0$ (c $\left.0.05, \mathrm{MeOH}\right)$; IR (KBr) $v_{\max } 3330,2924,2861,1767,1735,1646,1069,1023 \mathrm{~cm}^{-1}$; UV (MeOH) $\lambda_{\max }(\log \varepsilon) \mathrm{nm}$; 264.0 (4.29), 202.0 (4.10); for ${ }^{1} \mathrm{H}$ - and ${ }^{13} \mathrm{C}-\mathrm{NMR}\left(\mathrm{C}_{5} \mathrm{D}_{5} \mathrm{~N}, 400 \mathrm{MHz}\right)$ see Tables 1 and 2; HRESI-MS m/z 1058.5658 [M+Na] ${ }^{+}$(calcd. 1058.5664).

Heinsiagenin A 3 - $O$ - $[\alpha$-L-rhamnopyranosyl-( $1 \rightarrow 2)$ - $\beta$-D-glucopyranosyl- $(1 \rightarrow 2)]$ - $[\beta$-D-

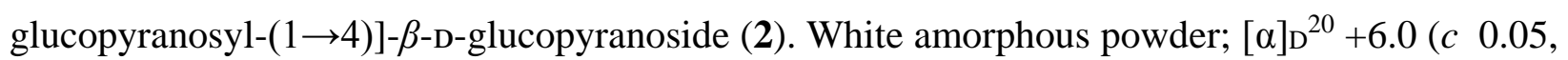
$\mathrm{MeOH})$; IR (KBr) $v_{\max } 3305,2924,2871,1645,1068,1025 \mathrm{~cm}^{-1}$; UV (MeOH) $\lambda_{\max }(\log \varepsilon) \mathrm{nm}$; 264.0 (4.04); for ${ }^{1} \mathrm{H}$ - and ${ }^{13} \mathrm{C}-\mathrm{NMR}\left(\mathrm{C}_{5} \mathrm{D}_{5} \mathrm{~N}, 400 \mathrm{MHz}\right)$ see Tables 1 and 2; HR-ESI-MS $\mathrm{m} / z$ $1220.6163[\mathrm{M}+\mathrm{Na}]^{+}$(calcd. 1220.6192) and $1196.6216[\mathrm{M}-\mathrm{H}]^{-}($calcd. 1196.6217).

$2 \alpha$-Hydroxyheinsiagenin A 3-O-[ $\alpha$-L-rhamnopyranosyl-( $1 \rightarrow 2)$ - $\beta$-D-glucopyranosyl-( $1 \rightarrow 2)]$ $\beta$-D-glucopyranoside (3). White amorphous powder; $[\alpha]_{\mathrm{D}}{ }^{20}+6.0(c \quad 0.05, \mathrm{MeOH}) ; \mathrm{IR}(\mathrm{KBr}) v_{\max }$ 3337, 2924, 2866, 1766, 1649, 1071, 1039, $1023 \mathrm{~cm}^{-1}$; UV (MeOH) $\lambda_{\max }(\log \varepsilon) \mathrm{nm} ; 262.0$ (4.78); for ${ }^{1} \mathrm{H}$ - and ${ }^{13} \mathrm{C}-\mathrm{NMR}\left(\mathrm{C}_{5} \mathrm{D}_{5} \mathrm{~N}, 400 \mathrm{MHz}\right)$ see Tables 1 and 2; HR-ESI-MS $m / z, 1050.5730$ $[\mathrm{M}-\mathrm{H}]^{-}$(calcd. 1050. 5637) and $\mathrm{m} / z$. 1086.5535 [M+Cl] $^{-}$(calcd. 1086. 5404).

$2 \alpha$-Hydroxyheinsiagenin A 3-O-[ $\beta$-D-glucopyranosyl- $(1 \rightarrow 2)]$-[ $\beta$-D-glucopyranosyl]- $(1 \rightarrow 4)]$ $\beta$-D-glucopyranoside (4). Yellowish white amorphous powder; $[\alpha]_{\mathrm{D}^{20}}+10.0(c \quad 0.05, \mathrm{MeOH})$; IR (KBr) $v_{\max } 3347,2921,2889,1769,1640,1069,1038 \mathrm{~cm}^{-1}$; UV (MeOH) $\lambda_{\max }(\log \varepsilon) \mathrm{nm} ; 262.0$ (3.92); for ${ }^{1} \mathrm{H}$ - and ${ }^{13} \mathrm{C}-\mathrm{NMR}\left(\mathrm{C}_{5} \mathrm{D}_{5} \mathrm{~N}, 400 \mathrm{MHz}\right)$ see Tables 1 and 2; HR-ESI-MS $m / z, 1090.5656$ $[\mathrm{M}+\mathrm{Na}]^{+}$(calcd. 1090.5562) and $\mathrm{m} / \mathrm{z} 1066.5856$ [M-H] $^{-}$(calcd. 1066.5586). 
$N$-(2S, 3R, 4R-3-methyl-4-pentanolid-2-yl)-18-hydroxylanosta-8 (9), 22E, 24E-trien-27amide-3- $O$-[ $\alpha$-L-rhamnopyranosyl-( $1 \rightarrow 2)$ - $O$ - $\beta$-D-glucopyranosyl-( $1 \rightarrow 2)]$-[ $\beta$-D-glucopyranosyl$(1 \rightarrow 4)]-\beta$-D-glucopyranoside (5). Yellowish white amorphous powder; $[\alpha]_{\mathrm{D}}{ }^{20}+10.0(c \quad 0.02$, $\mathrm{CH}_{3} \mathrm{OH}$ ); IR (KBr) $v_{\max } 3366,2926,1767,1070,1046 \mathrm{~cm}^{-1}$; UV (MeOH) $\lambda_{\max }(\log \varepsilon) \mathrm{nm} ; 261.0$ (3.94), 255.0 (3.95); for ${ }^{1} \mathrm{H}-$ and ${ }^{13} \mathrm{C}-\mathrm{NMR}\left(\mathrm{C}_{5} \mathrm{D}_{5} \mathrm{~N}, 400 \mathrm{MHz}\right)$ see Tables 1 and 2; HR-ESI-MS $m / z$ 1236.6196 [M+Na] ${ }^{+}$(calcd. 1236.6141).

\subsection{Biological activities}

\subsubsection{Antiprotozoal assay}

Compounds 1-5 were tested for their antiprotozoal activities against Leishmania donovani Promastigote, L. donovani Amastigote, L. donovani Amastigote/THP1 cells and Trypanosoma brucei brucei employing the methods described previously [11]. The in vitro antileishmanial and antitrypanosomal assays were done on cell cultures of $L$. donovani promastigotes, axenic amastigotes, THP1-amastigotes, and Trypanosoma brucei trypomastigotes by Alamar Blue assays as described earlier [11]. The assays have been adapted to 384 well micro-plate format. In a 384 well micro-plate, the samples with appropriate dilution were added to the L. donovani promastigotes or L. donovani axenic amastigotes or $T$. bruei trypomastigotes cultures $\left(2 \times 10^{6}\right.$ cell $/ \mathrm{mL})$. The compounds were tested at three concentrations ranging from $40-1.6 \mu \mathrm{g} / \mathrm{mL}$ or 10 $0.25 \mu \mathrm{g} / \mathrm{mL}$. The plates were incubated at $26^{\circ} \mathrm{C}$ for $72 \mathrm{~h}\left(37^{\circ} \mathrm{C}\right.$ for axenic amastigotes and $T$. brucei trypomastigotes) and growth of the parasites in cultures were determined by Alamar Blue assay [11]. The compounds were also tested against L. donovani intracellular amastigotes in THP1 cells employing a parasite-rescue and transformation assay [12]. The compounds were simultaneously tested for cytotoxicity against THP1 cell cultures. The conditions for seeding the THP1 cells, exposure to the test compounds and evaluation of cytotoxicity were the same as described in parasite-rescue and transformation assay [12]. $\mathrm{IC}_{50}$ and $\mathrm{IC}_{90}$ values were computed from the dose response curves using XLfit software. DFMO (difluoromethylornithine) was used as a positive control.

\subsubsection{Opioid and cannabinoid receptor binding assay}

This screen is designed to use a series of controls to determine the binding affinity of the test compounds using a 96-well format [13]. $10 \mu \mathrm{M}$ of a positive control [CP-55,940 for cannabinoid receptor binding screen] and [DPDPE (Delta), nor-Binaltorphimine dihydrochloride (Kappa) and DAMGO $(\mathrm{Mu})$ for opioid receptor binding screen] were used to ascertain non-specific 
binding (NSB) and 1\% ethanol or DMSO in Tris-EDTA buffer was used to ascertain total binding. To eliminate the possibility of contamination in the test compounds or controls, wells with $1 \%$ ethanol or DMSO with no membrane were tested. Each test well contained $100 \mu \mathrm{L}$ of the control, $10 \mu \mathrm{L}$ of test compound, or vehicle and $100 \mu \mathrm{L}$ cell membrane. Data was analyzed by a non-linear curve fit model using Graph Pad Prizm 5.04 software (GraphPad, La Jolla, CA) and $\mathrm{IC}_{50}$ values were calculated. The reaction was terminated via rapid filtration with cold Tris$\mathrm{HCl}$ buffer through a UniFilter GF/ B 96-well plate pre-soaked with 0.3\% BSA. When the filters were dry, $25 \mu \mathrm{L}$ MicroScint was applied to each filterand the plates were read on a Top Count NXT HTS Microplate Scintillation Counter where the counts per minute (CPM) were recorded. Non-specific binding was subtracted from the total binding to find specific binding. Purified compounds exhibiting $50 \%$ or greater displacement of radioligand were screened for IC50 values which were calculated by a non-linear curve fit model using Graph Pad Prizm 5.0 software. Naloxone $\mathrm{HCl}$ was used as a positive control.

\subsection{Acidic hydrolysis}

About $2 \mathrm{mg}$ of each saponin (1-5) were refluxed with $1 \mathrm{~N} \mathrm{HCl}(0.5 \mathrm{ml})$ at $88{ }^{\circ} \mathrm{C}$ for $6 \mathrm{~h}$. The reaction mixtures were partitioned with an equal amount of $\mathrm{CHCl}_{3}(0.5 \mathrm{ml})$, and the aqueous layers of the hydrolysates were analyzed for their sugar components.

\subsection{GC/FID trimethylsilyl derivatization}

Dried aqueous layers of the hydrolysates of compounds 1-5 (approximately. $100 \mu \mathrm{g}$ each) were treated separately with pyridine $(5 \mu \mathrm{L}$, silylation grade, Pierce) and BSTFA (N,Obis(trimethylsilyl)-trifluoroacetamide) $(100 \mu \mathrm{L}+98 \%$ Acros Organics), followed by heating at $75{ }^{\circ} \mathrm{C}$ for $1 \mathrm{~h}$, after cooling to room temperature. $\mathrm{CH}_{2} \mathrm{Cl}_{2}(1 \mathrm{~mL})$ was added to the reaction mixture. The solution analyzed by GC/FID and compared with standard D-glucose and Lrhamnose after derivatization.

\section{Results and discussion}

Compound 1 was isolated as a faint yellow amorphous powder. Its positive HR-ESI-MS data suggested the molecular formula $\mathrm{C}_{54} \mathrm{H}_{85} \mathrm{NO}_{18}$ by providing a molecular ion peak at $\mathrm{m} / z$ 1058.5658 $[\mathrm{M}+\mathrm{Na}]^{+}$(calcd. 1058.5664). In the ${ }^{1} \mathrm{H}-\mathrm{NMR}$ spectrum, three characteristic signals were observed at $\delta_{H} 9.002(1 \mathrm{H}, d, 7.2 \mathrm{~Hz}, \mathrm{NH}), \delta_{H} 0.229(1 \mathrm{H}, d, 4.4 \mathrm{~Hz}, \mathrm{H}-19 \mathrm{a})$, and $\delta_{H} 0.527$ $(1 \mathrm{H}, d, 4.0 \mathrm{~Hz}, \mathrm{H}-19 \mathrm{~b})$ suggesting that the compound possessed an amide group and an upfield 
cyclopropane group in its aglycone as found in several saponins from the same genus [3]. The spectrum also showed signals corresponding to four tertiary and three secondary methyl groups and one vinylic methyl group. Comparison of the ${ }^{1} \mathrm{H}$ - and ${ }^{13} \mathrm{C}-\mathrm{NMR}$ spectral data of compound 1 with those of saponins previously reported from the genus confirmed heinsiagenin A, a cycloartane with an $\alpha$-amino- $\gamma$-lactone in an amide form in the side chain, to be its aglycone with a saccharide chain connected to its C-3 position. The amino group forms part of a 4hydroxyisoleucine residue present in the $\gamma$-lactone form [14]. This peculiar free amino acid 4hydroxyisoleucine and its corresponding cis $\gamma$-lactone have been previously reported from nature [15]. The ${ }^{1} \mathrm{H}-\mathrm{NMR}$ spectrum of compound 1 showed a doublet methyl signal at $\delta_{H}(1.84, J=6.0$ $\mathrm{Hz})$, an anomeric proton singlet at $\delta_{H} 6.39$, two anomeric proton doublets at $\delta_{H}(5.00, \mathrm{~J}=7.2 \mathrm{~Hz}$ and 5.83, $J=7.6 \mathrm{~Hz}$ ) arising from sugar units which suggested the presence of one L-rhamnose and two D-glucose moieties. Further support was obtained from the ${ }^{13} \mathrm{C}$-NMR spectrum which showed three anomeric carbon signals appeared at $\delta_{C} 105.5,102.52$ and 102.50. Acidic hydrolysis of compound $\mathbf{1}$ yielded D-glucose and L-rhamnose as its sugar components as identified from their retention times (3.39 and 1.70, respectively) using GC after silylation with BSTFA as compared to standard sugars. The relative stereochemistry of the rhamnose unit was determined as $\alpha$-L-rhamnose based on the broad singlet of its anomeric proton while the two Dglucose units were in $\beta$-glycosidic linkage by their large ${ }^{3} J_{H 1, H 2}$ coupling constants (7.2, and 7.6 $\mathrm{Hz}$ ). The structure of the saccharide moiety was established based on the significant HMBC correlations observed between $\mathrm{H}_{\mathrm{G}-1} / \mathrm{C}-3$ of the aglycone, $\mathrm{H}_{\mathrm{G}^{\prime}-1} / \mathrm{C}_{\mathrm{G}-2}\left(\delta_{C} 79.9\right)$, and $\mathrm{H}_{\mathrm{R}-1} / \mathrm{C}_{\mathrm{G}^{\prime}-2}\left(\delta_{C}\right.$ 79.1) (Fig. 2). The above results were consistent with the ${ }^{13} \mathrm{C}-\mathrm{NMR}$ chemical shifts of the three sugar units reported in table 2 . Therefore, the structure of compound $\mathbf{1}$ was determined to be heinsiagenin $\quad \mathrm{A} \quad 3-O$ - $[\alpha$-L-rhamnopyranosyl- $(1 \rightarrow 2)-\beta$-D-glucopyranosyl- $(1 \rightarrow 2)]-\beta$-Dglucopyranoside, which is a new natural compound.

Compound 2 was obtained as a white amorphous powder. Its positive HR-ESI-MS suggested the molecular formula of $\mathrm{C}_{60} \mathrm{H}_{95} \mathrm{NO}_{23}$ by a molecular ion peak at $\mathrm{m} / z 1220.6163[\mathrm{M}+\mathrm{Na}]^{+}$(calcd. 1220.6192) and confirmed by the negative HR-ESI-MS by provididing a molecular ion peak at $\mathrm{m} / \mathrm{z} 1196.6216[\mathrm{M}-\mathrm{H}]^{-}$(calcd. 1196.6217). On the basis of ${ }^{1} \mathrm{H}-$ and ${ }^{13} \mathrm{C}-\mathrm{NMR}$ spectra, the aglycone of compound 2 was identified as heinsiagenin $\mathrm{A}$ as that of compound $\mathbf{1}$. In its ${ }^{13} \mathrm{C}$ NMR spectrum, four anomeric carbon signals were observed at $\delta_{C} 106.0,102.5,101.8$ and 105.2. Only D-glucose and L-rhamnose were identified in the aqueous layer of the hydrolysate as in 
compound 1. The structure of the saccharide moiety was established based upon the HMBC correlations observed between $\mathrm{HG}_{\mathrm{G}-1} / \mathrm{C}-3$ of the aglycone, $\mathrm{H}_{\mathrm{G}^{\prime}-1} / \mathrm{C}_{\mathrm{G}-2}$, and $\mathrm{HR}_{\mathrm{R}-1} / \mathrm{C}_{\mathrm{G}^{\prime}-2}$ (Fig. 2). Both of G-6 and G'-6 carbon resonances were not affected by glycosidic linkage so connection of the third glucosyl unit should be in C-4 of one of the already established two glucosyl units G or G'. In the HMBC spectrum of compound 2 , cross peak signal was observed between $\mathrm{H}_{\mathrm{G}}$-1 1 and $\mathrm{C}_{\mathrm{G}-4}$ (Fig. 2). Therefore, the interglycosidic linkages among all the four sugar units were determined and the structure of compound 2 was identified as heinsiagenin A 3- $O$-[ $\alpha$-L-rhamnopyranosyl$(1 \rightarrow 2)$ - $\beta$-D-glucopyranosyl-( $1 \rightarrow 2)]$-[ $\beta$-D-glucopyranosyl-( $1 \rightarrow 4)]$ - $\beta$-D-glucopyranoside, which is being isolated for the first time from the nature.

Compound $\mathbf{3}$ was isolated as a white amorphous powder. Its positive HR-ESI-MS data suggested the molecular formula $\mathrm{C}_{54} \mathrm{H}_{85} \mathrm{NO}_{19}$ by a molecular ion peak at $\mathrm{m} / \mathrm{z} 1074.5639$ $[\mathrm{M}+\mathrm{Na}]^{+}$(calcd. 1074.5613) and confirmed by the negative HR-ESI-MS by a molecular ion peak at $\mathrm{m} / z$ 1050.5730 [M-H] $]^{-}$(calcd. 1050.5637) and $\mathrm{m} / z$ 1086.5535 [M+Cl] ${ }^{-}$(calcd. 1086.5404). The ${ }^{1} \mathrm{H}-\mathrm{NMR}$ spectrum showed the characteristic signals of heinsiagenin A except for the presence of an oxygen-bearing methine at $\delta_{H} 4.052\left(\delta_{C} 70.1\right)$, which showed a correlation with $\mathrm{H}-3$ at $\delta_{H}$ 3.374 in the ${ }^{1} \mathrm{H}-{ }^{1} \mathrm{H}$ COSY spectrum. Also, an HMBC correlation from $\mathrm{H}-3$ to this methine was observed which clearly suggested the presence of an $\alpha$-hydroxy group at C-2. This finding was supported by the significant downfield shift of C-3 (appears at $\delta_{C} 96.0$ compared to around $\delta_{C}$ 90.0 for saponins with heinsiagenin $\mathrm{A}$ as in compounds $\mathbf{1}$ and 2). The configuration of C-2 hydroxy group was deduced from the ROESY spectrum and further supported by the comparison of its ${ }^{13} \mathrm{C}$ chemical shifts to the previously reported data of the analogues [5]. To our knowledge, only one saponin which contians the same aglycone but linked to two glucose and two rhamnose units has been previously reported [5]. The ${ }^{1} \mathrm{H}-\mathrm{NMR}$ spectrum of compound $\mathbf{3}$ showed a doublet methyl signal at $\delta_{H}(1.82, J=5.6 \mathrm{~Hz})$, an anomeric proton singlet at $\delta_{H} 6.40$, two anomeric proton doublets at $\delta_{H}(5.01, J=7.2 \mathrm{~Hz}$ and $5.89, J=7.6 \mathrm{~Hz})$ belonging to sugar units which suggested the presence of one L-rhamnose and two D-glucose moieties. The ${ }^{13} \mathrm{C}-\mathrm{NMR}$ spectrum of compound 3 showed signals for the three anomeric carbons appeared at $\delta_{C} 105.3,102.6$, and 102.7 and the acidic hydrolysis of compound $\mathbf{3}$ yielded D-glucose and L-rhamnose as its sugar components which were identified using the same method as for compounds $\mathbf{1}$ and $\mathbf{2}$. The sequence and interglycosidic linkages of sugar units were determined based upon the HMBC correlations observed between $\mathrm{H}_{\mathrm{G}-1} / \mathrm{C}-3$ of the aglycone, and $\mathrm{H}_{\mathrm{G}^{\prime}-1} / \mathrm{C}_{\mathrm{G}-2}$ which confirmed the 
connection of another glucosyl unit at position 2 of the first glucose unit G (Fig. 2). The HMBC cross peak between $\mathrm{HR}_{\mathrm{R}-1}$ and $\mathrm{C}_{\mathrm{G}^{\prime}-2}$ confirmed the connection of the rhamnosyl unit at position 2 of the second $G^{\prime}$ (Fig. 2). Therefore, the structure of the compound was determined to be $2 \alpha-$ hydroxyheinsiagenin A 3 - $O$-[ $\alpha$-L-rhamnopyranosyl- $(1 \rightarrow 2)-\beta$-D-glucopyranosyl- $(1 \rightarrow 2)]-\beta$-Dglucopyranoside, which is a new secondary metabolite.

Compound 4 was obtained as a faint yellow amorphous powder. Its positive HR-ESI-MS suggested the molecular formula $\mathrm{C}_{54} \mathrm{H}_{85} \mathrm{NO}_{18}$ by a molecular ion peak at $\mathrm{m} / z 1090.5656$ $[\mathrm{M}+\mathrm{Na}]^{+}$(calcd. 1090.5562) and confirmed by the negative HR-ESI-MS by a molecular ion peak at $m / z$ 1066.5856 [M-H] ${ }^{-}$(calcd. 1066.5586). Comparison of the ${ }^{1} \mathrm{H}$ - and ${ }^{13} \mathrm{C}-\mathrm{NMR}$ spectra of compound 4 with those of compound 3 , confirmed $2 \alpha$-hydroxyheinsiagenin A to be its genin. The ${ }^{1} \mathrm{H}-\mathrm{NMR}$ spectrum of compound 4 showed three anomeric proton doublets at $\delta_{H}(4.86, J=$ $7.2 \mathrm{~Hz}, 5.61, J=7.6 \mathrm{~Hz}$, and $5.07, J=7.6 \mathrm{~Hz}$ ) which suggested the presence of three D-glucose moieties and confirmed from the ${ }^{13} \mathrm{C}$-NMR spectrum which showed the three anomeric carbon resonances at $\delta_{C}$ 104.8, 105.3 and 106.2. Acidic hydrolysis of the compound yielded only Dglucose as its sugar component. The three D-glucose units were in $\beta$-glycosidic linkage as deduced by their large ${ }^{3} J_{H 1, H 2}$ coupling constants $(7.2$, and $7.6 \mathrm{~Hz})$. The structure of the saccharide moiety was deduced from the significant HMBC cross peaks appeared between G1/C-3 of the aglycone, $\mathrm{H}_{\mathrm{G}^{\prime}-1} / \mathrm{C}_{\mathrm{G}-2}$ (its assignment was clear from the ${ }^{1} \mathrm{H}-{ }^{1} \mathrm{H}$ COSY correlations), and between $\mathrm{HG}_{\mathrm{G}-1} / \mathrm{C}_{\mathrm{G}-4}$ (Fig. 2) which revealed the presence of a 2,4-branched glucose and two terminal glucose units. The ${ }^{13} \mathrm{C}-\mathrm{NMR}$ chemical shifts of compound $\mathbf{4}$ was consistent with the above suggested interglycosidic linkages between the three glucose units. Accordingly, compound 4 was assigned as $2 \alpha$-hydroxyheinsiagenin A 3- $O$-[ $\beta$-D-glucopyranosyl- $(1 \rightarrow 2)]-[\beta$-Dglucopyranosyl-( $1 \rightarrow 4)$ ]- $\beta$-D-glucopyranoside, which is a newly reported natural compound.

Compound 5, a faint yellow amorphous powder, its positive HR-ESI-MS exhibited the molecular formula of $\mathrm{C}_{60} \mathrm{H}_{95} \mathrm{NO}_{24}$ by a molecular ion peak at $\mathrm{m} / z 1236.6196[\mathrm{M}+\mathrm{Na}]^{+}$(calcd. 1236.6141). Comparison of its spectral data with those of compounds 1-4 revealed that compound 5 had a lanostene-type sapogenin with an identical side chain as that of 1-4 and the difference between them occurred in its triterpene skeleton functions. The ${ }^{1} \mathrm{H}-\mathrm{NMR}$ spectrum showed the absence of the characteristic cyclopropane-methylene signals, the absence of a methyl signal for $\mathrm{H}-18$ and the presence of a $\mathrm{CH}_{2}$ signal at $\delta_{C} 62.9$ correlated in $\mathrm{HMQC}$ with two protons at $\delta_{H} 3.787$ and 3.892, which in turn showed a long-range coupling in HMBC with C-17 
at $\delta_{C} 50.8$. The last two protons were coupled only to each other $(J=10.4$ and $11.2 \mathrm{~Hz}$ ), which indicate the existence of a quaternary hydroxymethyl substituent. Moreover, two additional quaternary olefinic carbon signals $\left(\delta_{C} 134.4\right.$ and 136.8$)$ were observed in the ${ }^{13} \mathrm{C}-\mathrm{NMR}$. From the NMR data, the tetra-substituted double bond was located at C8-C9. This assignment showed a similar pattern as that of the Mussaenoside Q sapogenin [5]. Four anomeric proton signals were observed in the ${ }^{1} \mathrm{H}$-NMR spectrum including three $\beta$-D-glucosyl units and one $\alpha$-L-rhamnosyl unit as confirmed by hydrolysis as with compounds 1-4. The structure of the saccharide moiety was the same as that observed in compound 2 which clearly deduced from a matched ${ }^{13} \mathrm{C}-\mathrm{NMR}$ sugar regions of both compounds. Additionally, the structure was confirmed through observation

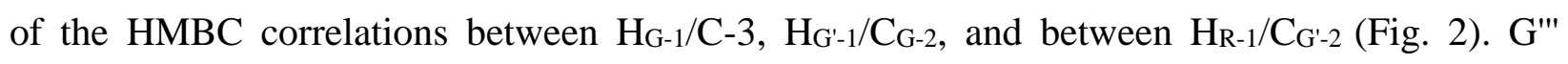
unit's linkage was confirmed by the HMBC cross peaks between $\mathrm{HG}_{G}{ }^{-1} / \mathrm{CG}_{\mathrm{G}-4}$ (Fig. 2). Therefore, the structure of compound 5 was elucidated as $N$-(2S, 3R, 4R-3-methyl-4-pentanolid-2-yl)-18hydroxylanosta-8 $\quad(9), \quad 22 E, \quad 24 E$-trien-27-amide-3- $O$-[ $\alpha$-L-rhamnopyranosyl- $(1 \rightarrow 2)-\beta$-D-

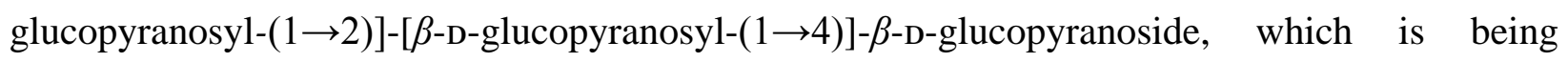
reported from nature for the first time. To the best of our knowledge, only one saponin possessing the same sapogenin was previously isolated from $M$. pubescens [5].

The relative configurations of compounds (1-5) were determined based on the analysis of the coupling constants of relevant hydrogens, comparison with reported data of analogous compounds with configuration described in the literature and confirmed through analysis of the ROESY spectra, which showed significant cross peaks between $\mathrm{H}-3 / \mathrm{H}_{\mathrm{G}-1}, \mathrm{H}-3$ '/H-4', H-22/H-24, NH/H-22, NH/H-24, H-24/H-4', H-22/H-4', H-22/H-3', and H-23/Me-26. Moreover, the absence of ROESY cross peaks between H-3 and H-2 in compounds $\mathbf{3}$ and $\mathbf{4}$ further confirmed the opposite orientations in these positions [3-5].

Heinsiagenin A saponins have been previously reported from Heinsia crinata [14], and Mussaenda pubescens [3-5] which might be useful for the chemotaxonomic evaluation and relationships within Rubiaceae family as both genera are closely related (the same tribe Mussaendeae) [16].

Compounds 1-5 were evaluated for their antiprotozoal activities and cannabinoid and opioid receptor binding affinities. Compound 1 showed potent antitrypanosomal activity with an $\mathrm{IC}_{50}$ value of $8.80 \mu \mathrm{M}$. Compounds $\mathbf{2 - 4}$ showed highly potent antitrypanosomal activity with $\mathrm{IC}_{50}$ values of $2.57,2.61$ and $2.84 \mu \mathrm{M}$, respectively and $\mathrm{IC}_{90}$ values of $3.56,3.36$, and $4.35 \mu \mathrm{M}$, 
respectively while compound $\mathbf{5}$ showed no antitrypanosomal activity within the tested concentrations range $(0.32-8.23 \mu \mathrm{M})$. The antitrypanosomal activities compared to the positive control DFMO, which has IC50 and IC90 values of 13.06 and $28.99 \mu \mathrm{M}$, respectively. Compounds $\mathbf{1}$ and 2 showed moderate activities in $\mu$-opioid receptor binding assay with 65.9 and $61.0 \%$ radio ligand displacement, respectively $\left(\mathrm{K}_{\mathrm{i}}\right.$ values of $9.94 \mu \mathrm{M}$ and $0.87 \mu \mathrm{M}$, respectively and $\mathrm{IC}_{50}$ values of $19.87 \mu \mathrm{M}$ and $1.74 \mu \mathrm{M}$, respectively) compared to the $\mathrm{K}_{\mathrm{i}}$ and $\mathrm{IC}_{50}$ values of $1.96 \mathrm{nM}$ and $3.92 \mathrm{nM}$ for the positive control, naloxone $\mathrm{HCl}$.

\section{Acknowledgements}

We are grateful to the Egyptian Government, the National Center for Natural Products Research, The University of Mississippi, USA, NIH NIGMS COBRE grant P20GM104932, USA-ARS scientific cooperative agreement and UD department of defense CDMRP grant W81XWH-09-0093 (BLT) for their financial support. The content is solely the responsibility of the authors and does not necessarily represent the official views of the aforementioned institutions. We are also thankful to Dr. Baharthi Avula for providing the HR-ESI-MS.

\section{Supporting information}

NMR and HR-ESI-MS spectra of compounds 1-5.

\section{References}

[1] Vidyalakshmi KS, Nagarajan S, Vasanthi HR, Rajamanickam V. Hepatoprotective and antioxidant activity of two iridoids from Mussaenda 'dona aurora'. Z. Naturforsch., C: Biosci 2009;64:329-34.

[2] Vidyalakshmi KS, Vasanthi HR, Rajamanickam GV. Ethnobotany, Phytochemistry and Pharmacology of Mussaenda Species (Rubiaceae). J Ethnobot Leaflets 2008;12:469-75.

[3] Zhao W, Wolfender JL, Iiostettmann K, Cheng K, Xu R, Qin G. Triterpenes and triterpenoid saponins from Mussaenda pubescens. Phytochemistry 1997;45:1073-8.

[4] Zhao W, Xu R, Qin G, Tang X, Li X. Chemical constituents from Mussaenda pubescens. Nat Prod Sci 1995;1:61-5.

[5] Zhao W, Xu J, Qin G, Xu R. New triterpenoid saponins from Mussaenda pubescens. J Nat Prod 1994;57:1613-8. 
[6] Liu S, Cui M, Liu Z, Song F. Structural analysis of saponins from medicinal herbs using electrospray ionization tandem mass spectrometry. J Am Soc Mass Spectrom 2003;15:13341.

[7] Atawodi SE, Bulus T, Ibrahim S, Ameh DA, Nok AJ, Mamman M, Galadima M. In vitro trypanocidal effect of methanolic extract of some Nigerian savannah plants. Afr J Biotechnol 2004;2:317-21.

[8] Brun R, Balmer O. New developments in human African trypanosomiasis. Curr Opin Infect Dis 2006, 19(5), 415-20.

[9] Steverding D. The development of drugs for treatment of sleeping sickness: a historical review. Parasit Vectors 2010; 3:15.

[10] Steverding D, Tyler KM. Novel antitrypanosomal agents. Expert Opinion on Investigational Drugs 2005;14:939-55.

[11] Manda S, Khan SI, Jain SK, Mohammed S, Tekwani BL, Khan IA, Vishwakarma RA, Bharate SB. Synthesis, antileishmanial and antitrypanosomal activities of N-substituted tetrahydro- $\beta$-carbolines. Bioorg Med Chem Lett 2014;24:3247-50.

[12] Jain SK, Sahu R, Walker LA, Tekwani BL. A Parasite Rescue and Transformation Assay for Antileishmanial Screening Against Intracellular Leishmania donovani Amastigotes in THP1 Human Acute Monocytic Leukemia Cell Line. J Vis Exp 2012;70:4054.

[13] Atta-ur-Rahman, Choudhary M, Thomsen WJ. Bioassay techniques for drug development. The Netherlands: Hawood Academic Publishers; 2001:16.

[14] Babadybila, Kilonda A, Toppet S, Compernolle F, Hoornaert G. New triterpenes from Heinsia crinata. Tetrahedron 1989; 45:5907-16.

[15] Broca C, Manteghetti M, Gross R, Baissac Y, Jacob M, Petit P, Ribes G. 4Hydroxyisoleucine: effects of synthetic and natural analogues on insulin secretion. Eur. J. Pharmacol. 2000;390:339-45.

[16] Kainulainen K, Razafimandimbison SG, Bremer B. Phylogenetic relationships and new tribal delimitations in subfamily Ixoroideae (Rubiaceae). Bot. J. Linn Soc. 2013;173:387-406. 
Table 1

${ }^{1} \mathrm{H}$ and ${ }^{13} \mathrm{C}$-NMR spectroscopic data of the aglycones for compounds $\mathbf{1 - 5}\left(\mathrm{C}_{5} \mathrm{D}_{5} \mathrm{~N}, 400,100 \mathrm{MHz}\right)$.

\begin{tabular}{|c|c|c|c|c|c|c|c|c|c|c|}
\hline \multirow{2}{*}{ Position } & \multicolumn{2}{|l|}{1} & \multicolumn{2}{|l|}{2} & \multicolumn{2}{|l|}{3} & \multicolumn{2}{|l|}{4} & \multicolumn{2}{|l|}{5} \\
\hline & $\delta_{H}(J$ in $\mathrm{Hz})$ & $\delta_{C}$ type & $\delta_{H}(J$ in $\mathrm{Hz})$ & $\delta_{C}$ type & $\delta_{H}(J$ in $\mathrm{Hz})$ & $\delta_{C}$ type & $\delta_{H}(\mathrm{~J}$ in $\mathrm{Hz})$ & $\delta_{C}$ type & $\delta_{H}(J$ in $\mathrm{Hz})$ & $\delta_{C}$ type \\
\hline 1 & $1.15,1.51, m$ & $32.6 \mathrm{t}$ & $1.13,1.50, \mathrm{~m}$ & $32.7 \mathrm{t}$ & $1.86,1.78, m$ & $40.9 \mathrm{t}$ & $1.70,1.83, \mathrm{~m}$ & $40.9 \mathrm{t}$ & $1.10,1.57, \mathrm{~m}$ & $36.4 \mathrm{t}$ \\
\hline 2 & $1.91,2.36, m$ & $30.2 \mathrm{t}$ & $1.28,2.281, m$ & $30.5 \mathrm{t}$ & $4.05, m$ & $70.1 \mathrm{~d}$ & $4.03, m$ & $69.7 \mathrm{~d}$ & $1.71,2.04, m$ & $28.9 \mathrm{t}$ \\
\hline 3 & $3.51, d d(11.6,4.0)$ & $90.1 \mathrm{~d}$ & $3.47, d d(11.2,4.4)$ & $90.4 \mathrm{~d}$ & $3.37, d(9.2)$ & $96.8 \mathrm{~d}$ & $3.27, d(9.2)$ & $96.0 \mathrm{~d}$ & $3.30, d d,(10.8,3.6)$ & $90.5 \mathrm{~d}$ \\
\hline 4 & - & $41.9 \mathrm{~s}$ & - & $41.9 \mathrm{~s}$ & - & $41.8 \mathrm{~s}$ & - & $42.7 \mathrm{~s}$ & - & $40.2 \mathrm{~s}$ \\
\hline 5 & $1.34, m$ & $48.2 \mathrm{~d}$ & $1.36, m$ & $48.2 \mathrm{~d}$ & $1.51, m$ & $48.3 \mathrm{~d}$ & $1.48, m$ & $48.1 \mathrm{~d}$ & $1.14, m$ & $51.6 \mathrm{~d}$ \\
\hline 6 & $0.77,1.60, m$ & $21.7 \mathrm{t}$ & $0.75,1.60, m$ & $21.7 \mathrm{t}$ & $0.80,1.58, m$ & $21.7 \mathrm{t}$ & $0.71,1.33, m$ & $20.3 \mathrm{t}$ & $1.98,1.32, m$ & $18.9 \mathrm{t}$ \\
\hline 7 & $1.21,1,10, m$ & $27.2 \mathrm{t}$ & $1.28,1,09, \mathrm{~m}$ & $27.1 \mathrm{t}$ & $1.28,1.15, m$ & $26.6 \mathrm{t}$ & $1.05,0.92, \mathrm{~m}$ & $26.5 \mathrm{t}$ & $2.60,1,69, m$ & $26.1 \mathrm{t}$ \\
\hline 8 & $1.51, m$ & $48.5 \mathrm{~d}$ & $1.47, m$ & $48.5 \mathrm{~d}$ & $1.57, m$ & $48.0 \mathrm{~d}$ & $1.47, d d(11.2,4.4)$ & $47.7 \mathrm{~d}$ & - & $134.4 \mathrm{~s}$ \\
\hline 9 & - & $18.9 \mathrm{~s}$ & - & $18.9 \mathrm{~s}$ & - & $20.0 \mathrm{~s}$ & - & $19.3 \mathrm{~s}$ & - & $136.8 \mathrm{~s}$ \\
\hline 10 & - & $26.7 \mathrm{~s}$ & - & $26.6 \mathrm{~s}$ & - & $25.7 \mathrm{~s}$ & - & $25.5 \mathrm{~s}$ & - & $37.4 \mathrm{~s}$ \\
\hline 11 & $1.14,1.90, m$ & $26.9 \mathrm{t}$ & $1.07,1.99, \mathrm{~m}$ & $27.2 \mathrm{t}$ & $1.02,2.00, \mathrm{~m}$ & $27.3 \mathrm{t}$ & $1.95,1.07, \mathrm{~m}$ & $27.4 \mathrm{t}$ & $2.12,2.29, \mathrm{~m}$ & $21.6 \mathrm{t}$ \\
\hline 12 & $1.60, m$ & $33.6 \mathrm{t}$ & $1.58, m$ & $33.6 \mathrm{t}$ & $1.59, m$ & $33.5 \mathrm{t}$ & $1.51, m$ & $33.3 \mathrm{t}$ & $2.01,1.48, m$ & $27.4 \mathrm{t}$ \\
\hline 13 & - & $46.2 \mathrm{~s}$ & - & $46.1 \mathrm{~s}$ & - & $46.1 \mathrm{~s}$ & - & $46.0 \mathrm{~s}$ & - & $50.1 \mathrm{~s}$ \\
\hline 14 & - & $49.7 \mathrm{~s}$ & - & $49.7 \mathrm{~s}$ & - & $49.7 \mathrm{~s}$ & - & $49.7 \mathrm{~s}$ & - & $51.5 \mathrm{~s}$ \\
\hline 15 & $1.29, m$ & $36.3 \mathrm{t}$ & $1.27, m$ & $36.3 \mathrm{t}$ & $1.29, m$ & $36.2 \mathrm{t}$ & $1.26, m$ & $36.3 \mathrm{t}$ & $1.60,1.29, m$ & $31.8 \mathrm{t}$ \\
\hline 16 & $1.58,1.27, m$ & $30.3 \mathrm{t}$ & $1.58,1.27, m$ & $29.3 \mathrm{t}$ & $1.52,1.24, m$ & $29.2 \mathrm{t}$ & $1.49,1.20, m$ & $29.2 \mathrm{t}$ & $1.55,1.28, m$ & $30.5 \mathrm{t}$ \\
\hline 17 & $1.65, m$ & $52.5 \mathrm{~d}$ & $1.60, m$ & $52.5 \mathrm{~d}$ & $1.61, m$ & $52.4 \mathrm{~d}$ & $1.56, m$ & $52.3 \mathrm{~d}$ & $1.71, m$ & $50.8 \mathrm{~d}$ \\
\hline 18 & $1.02, s$ & $18.9 \mathrm{q}$ & $1.00, s$ & $19.1 \mathrm{q}$ & $1.00, s$ & $18.9 \mathrm{q}$ & $0.97, s$ & $18.8 \mathrm{q}$ & $\begin{array}{l}3.79, d(11.2) \\
3.89, d(10.4)\end{array}$ & $62.9 \mathrm{t}$ \\
\hline 19 & $\begin{array}{l}0.23, d(4.4) \\
0.53, d(4.0)\end{array}$ & $30.1 \mathrm{t}$ & $\begin{array}{l}0.21, b r s \\
0.50, b r s\end{array}$ & $30.2 \mathrm{t}$ & $\begin{array}{l}0.33, d(4.0) \\
0.57, d(4.4)\end{array}$ & $30.1 \mathrm{t}$ & $\begin{array}{l}0.31, d(4.4) \\
0.52, d(4.4)\end{array}$ & $30.5 \mathrm{t}$ & $0.95, s$ & $19.6 \mathrm{q}$ \\
\hline 20 & $2.21, m$ & $41.8 \mathrm{~d}$ & $2.17, m$ & $41.9 \mathrm{~d}$ & $2.17, m$ & $41.8 \mathrm{~d}$ & $2.15, m$ & $41.8 \mathrm{~d}$ & $2.96, m$ & $42.3 \mathrm{~d}$ \\
\hline 21 & $1.03, d(5.2)$ & $20.4 \mathrm{q}$ & $1.01, d(4.8)$ & $20.5 \mathrm{q}$ & $1.01, d(5.6)$ & $19.8 \mathrm{q}$ & $0.98, d(5.6)$ & $19.7 \mathrm{q}$ & $1.41, d(6.0)$ & $21.9 \mathrm{q}$ \\
\hline 22 & $5.71, d d(14.4,8.4)$ & $148.5 \mathrm{~d}$ & $5.66, d d(15.2,9.2)$ & $148.5 \mathrm{~d}$ & $5.68, d d,(13.6,9.2)$ & $148.4 \mathrm{~d}$ & $5.62, d d$, overlapped & $148.3 \mathrm{~d}$ & $5.78, d d(15.2,9.6)$ & $149.6 \mathrm{~d}$ \\
\hline 23 & $6.45, d d(14.8,11.2)$ & $124.3 \mathrm{~d}$ & $\begin{array}{c}6.44, d d(14.4, \\
11.6)\end{array}$ & $124.2 \mathrm{~d}$ & $6.44, d d(15.2,11.2)$ & $123.5 \mathrm{~d}$ & $6.44, d d(14.8,11.2)$ & $124.2 \mathrm{~d}$ & $6.44, d d(14.4,11.6)$ & $123.5 \mathrm{~d}$ \\
\hline 24 & $7.30, d(10.8)$ & $135.4 \mathrm{~d}$ & $7.30, d(11.2)$ & $135.4 \mathrm{~d}$ & $7.29, d(10.8)$ & $135.3 \mathrm{~d}$ & $7.29, d(11.2)$ & $135.3 \mathrm{~d}$ & $7.32, d(10.8)$ & $135.5 \mathrm{~d}$ \\
\hline 25 & - & $129.6 \mathrm{~s}$ & - & $129.6 \mathrm{~s}$ & - & $129.6 \mathrm{~s}$ & - & $129.6 \mathrm{~s}$ & - & $129.3 \mathrm{~s}$ \\
\hline 26 & $2.21, s$ & $14.0 \mathrm{q}$ & $2.22, s$ & $14.1 \mathrm{q}$ & $2.22, s$ & $14.0 \mathrm{q}$ & $2.22, s$ & $14.0 \mathrm{q}$ & $2.16, s$ & $13.9 \mathrm{q}$ \\
\hline 27 & - & $171.3 \mathrm{~s}$ & - & $171.3 \mathrm{~s}$ & - & $171.2 \mathrm{~s}$ & - & $171.3 \mathrm{~s}$ & - & $171.3 \mathrm{~s}$ \\
\hline 28 & $1.19, s$ & $16.0 \mathrm{q}$ & $1.12, s$ & $15.9 \mathrm{q}$ & $1.25, s$ & $16.8 \mathrm{q}$ & $1.21, s$ & $16.8 \mathrm{q}$ & $1.12, s$ & $16.0 \mathrm{q}$ \\
\hline 29 & $1.42, s$ & $26.5 \mathrm{q}$ & $1.42, s$ & $26.9 \mathrm{q}$ & $1.47, \mathrm{~s}$ & $26.7 \mathrm{q}$ & $1.28, s$ & $26.2 \mathrm{q}$ & $1.39, \mathrm{~s}$ & $28.7 \mathrm{q}$ \\
\hline 30 & $0.93, s$ & $20.0 \mathrm{q}$ & $1.01, s$ & $19.8 \mathrm{q}$ & $0.92, s$ & $19.4 \mathrm{q}$ & $0.87, s$ & $19.9 \mathrm{q}$ & $1.09, s$ & $17.1 \mathrm{q}$ \\
\hline $1^{\prime}$ & - & $176.2 \mathrm{~s}$ & - & $176.3 \mathrm{~s}$ & - & $176.2 \mathrm{~s}$ & - & $176.3 \mathrm{~s}$ & - & $176.2 \mathrm{~s}$ \\
\hline 2 & $5.66, d d(7.6,7.2)$ & $56.0 \mathrm{~d}$ & $5.70, d d(7.6,7.2)$ & $55.9 \mathrm{~d}$ & $5.67, d d(7.6,7.2)$ & $56.0 \mathrm{~d}$ & $5.74, d d(7.6,7.2)$ & $55.9 \mathrm{~d}$ & $5.65, d d(7.6,6.8)$ & $56.0 \mathrm{~d}$ \\
\hline $\mathbf{3}^{\prime}$ & $2.95, m$ & $39.2 \mathrm{~d}$ & $2.94, m$ & $39.2 \mathrm{~d}$ & $2.93, m$ & $39.1 \mathrm{~d}$ & $2.92, m$ & $39.1 \mathrm{~d}$ & $2.92, m$ & $39.2 \mathrm{~d}$ \\
\hline $4^{\prime}$ & $4.71, m$ & $77.6 \mathrm{~d}$ & $4.71, m$ & $77.6 \mathrm{~d}$ & $4.69, m$ & $77.5 \mathrm{~d}$ & $4.69, m$ & $77.5 \mathrm{~d}$ & $4.69, m$ & $77.5 \mathrm{~d}$ \\
\hline 3'-Me & $0.88, d(7.2)$ & $8.6 \mathrm{q}$ & $0.89, d(8.4)$ & $8.8 \mathrm{q}$ & $0.89, d(7.2)$ & $8.6 \mathrm{q}$ & $0.88, d(6.8)$ & $8.7 \mathrm{q}$ & $0.89, d(7.2)$ & $8.6 \mathrm{q}$ \\
\hline 4'-Me & $1.21, d(6.4)$ & $15.9 \mathrm{q}$ & $1.20, d(6.4)$ & $15.8 \mathrm{q}$ & $1.21, d(6.4)$ & $16.0 \mathrm{q}$ & $1.18, d(6.4)$ & $15.9 \mathrm{q}$ & $1.21, d(6.4)$ & $15.9 \mathrm{q}$ \\
\hline NH & $9.00, d(7.2)$ & - & $9.16, d(7.6)$ & - & $9.01, d(7.2)$ & - & $9.25, d(7.6)$ & - & $8.97, d(7.2)$ & - \\
\hline
\end{tabular}


Table 2

${ }^{1} \mathrm{H}$ and ${ }^{13} \mathrm{C}$ NMR spectroscopic data of the sugar moieties for compounds $\mathbf{1 - 5}\left(\mathrm{C}_{5} \mathrm{D}_{5} \mathrm{~N}, 400,100 \mathrm{MHz}\right)$

\begin{tabular}{|c|c|c|c|c|c|c|c|c|c|c|}
\hline \multirow{2}{*}{ Position } & \multicolumn{2}{|c|}{1} & \multicolumn{2}{|c|}{2} & \multicolumn{2}{|c|}{3} & \multicolumn{2}{|l|}{4} & \multicolumn{2}{|c|}{5} \\
\hline & $\delta_{H}(J$ in $\mathrm{Hz})$ & $\delta_{C}$ type & $\delta_{H}(J$ in $\mathrm{Hz})$ & $\delta_{C}$ type & $\delta_{H}(J$ in $\mathrm{Hz})$ & $\delta_{C}$ type & $\delta_{H}(J$ in $\mathrm{Hz})$ & $\delta_{C}$ type & $\delta_{H}(J$ in $\mathrm{Hz})$ & $\delta_{C}$ type \\
\hline & \multicolumn{2}{|c|}{ G } & \multicolumn{2}{|c|}{$\mathrm{G}$} & \multicolumn{2}{|c|}{$\mathrm{G}$} & \multicolumn{2}{|l|}{$\mathrm{G}$} & \multicolumn{2}{|c|}{$\mathrm{G}$} \\
\hline 1 & $5.00, d(7.2)$ & $105.5 \mathrm{~d}$ & $4.92, d(7.2)$ & $105.2 \mathrm{~d}$ & $5.01, d(7.2)$ & $105.3 \mathrm{~d}$ & $4.86, d(7.2)$ & $104.8 \mathrm{~d}$ & $4.88, d(7.6)$ & $105.4 \mathrm{~d}$ \\
\hline 2 & $4.44, m$ & $79.9 \mathrm{~d}$ & $4.48, m$ & $78.5 \mathrm{~d}$ & $4.53, m$ & $79.8 \mathrm{~d}$ & $4.35, m$ & $81.6 \mathrm{~d}$ & $4.41, m$ & $78.6 \mathrm{~d}$ \\
\hline 3 & 4.57, $m$ & $78.4 \mathrm{~d}$ & $4.58, m$ & $77.6 \mathrm{~d}$ & 4.57, $m$ & $78.5 \mathrm{~d}$ & $4.20, m$ & $76.8 \mathrm{~d}$ & 4.57, $m$ & $77.6 \mathrm{~d}$ \\
\hline 4 & $4.09, m$ & $72.5 \mathrm{~d}$ & $4.16, m$ & $82.1 \mathrm{~d}$ & $4.11, m$ & $72.2 \mathrm{~d}$ & $4.24, m$ & $80.6 \mathrm{~d}$ & $4.18, m$ & $82.3 \mathrm{~d}$ \\
\hline 5 & $3.90, m$ & $78.0 \mathrm{~d}$ & $3.79, m$ & $76.5 \mathrm{~d}$ & $4.08, m$ & $78.3 \mathrm{~d}$ & $3.92, m$ & $77.2 \mathrm{~d}$ & $3.81, m$ & $76.5 \mathrm{~d}$ \\
\hline \multirow[t]{2}{*}{6} & $4.35,4.50, m$ & $63.3 \mathrm{t}$ & $4.34,4.57, m$ & $62.2 \mathrm{t}$ & $4.26,4.51, m$ & $62.8 \mathrm{t}$ & $4.39, m, 4.50, m$ & $62.0 \mathrm{t}$ & $4.33,4.55, m$ & $62.3 \mathrm{t}$ \\
\hline & \multicolumn{2}{|c|}{$G^{\prime}$} & \multicolumn{2}{|c|}{$\mathrm{G}^{\prime}$} & \multicolumn{2}{|c|}{$\mathrm{G}^{\prime}$} & \multicolumn{2}{|l|}{$\mathrm{G}^{\prime}$} & \multicolumn{2}{|c|}{$\mathrm{G}^{\prime}$} \\
\hline 1 & $5.83, d(7.6)$ & $102.50 \mathrm{~d}$ & $5.78, d(7.6)$ & $101.8 \mathrm{~d}$ & $5.89, d(7.6)$ & $102.6 \mathrm{~d}$ & $5.61, d(7.6)$ & $105.3 \mathrm{~d}$ & $5.74, d(7.2)$ & $101.9 \mathrm{~d}$ \\
\hline 2 & $4.29, m$ & $79.1 \mathrm{~d}$ & $4.32, m$ & $78.9 \mathrm{~d}$ & $4.34, m$ & $79.2 \mathrm{~d}$ & $4.12, m$ & $75.5 \mathrm{~d}$ & $4.28, m$ & $79.0 \mathrm{~d}$ \\
\hline 3 & $4.21, m$ & $79.6 \mathrm{~d}$ & $4.22, m$ & $75.6 \mathrm{~d}$ & $4.24, m$ & $79.9 \mathrm{~d}$ & $4.63, m$ & $77.5 \mathrm{~d}$ & 4.22, $m$ & $75.6 \mathrm{~d}$ \\
\hline 4 & 4.07, $m$ & $73.4 \mathrm{~d}$ & 4.07, $m$ & $73.4 \mathrm{~d}$ & $4.09, m$ & $73.4 \mathrm{~d}$ & $4.27, m$ & $72.5 \mathrm{~d}$ & $4.04, m$ & $73.5 \mathrm{~d}$ \\
\hline 5 & $3.87, m$ & $77.5 \mathrm{~d}$ & $4.11, m$ & $77.6 \mathrm{~d}$ & $3.90, m$ & $77.5 \mathrm{~d}$ & $3.93, m$ & $77.7 \mathrm{~d}$ & $4.12, m$ & $77.6 \mathrm{~d}$ \\
\hline \multirow[t]{2}{*}{6} & $4.32,4.48, m$ & $64.1 \mathrm{t}$ & $4.31,4.50, m$ & $64.0 \mathrm{t}$ & $4.34,4.57, m$ & $64.0 \mathrm{t}$ & $\begin{array}{c}4.37, d d(11.2,4.0) \\
4.53, m\end{array}$ & $63.5 \mathrm{t}$ & $4.27,4.48, m$ & $64.0 \mathrm{t}$ \\
\hline & \multicolumn{2}{|c|}{$\mathrm{R}$} & \multicolumn{2}{|c|}{$\mathrm{G}^{\prime \prime}$} & \multicolumn{2}{|c|}{$\mathrm{R}$} & \multicolumn{2}{|l|}{$\mathrm{G}^{\prime \prime}$} & \multicolumn{2}{|c|}{$G^{\prime \prime}$} \\
\hline 1 & $6.39, b r s$ & $102.52 \mathrm{~d}$ & $5.18, d(7.2)$ & $106.0 \mathrm{~d}$ & $6.40, b r s$ & $102.7 \mathrm{~d}$ & $5.07, d(7.6)$ & $106.2 \mathrm{~d}$ & $5.11, d,(7.6)$ & $105.9 \mathrm{~d}$ \\
\hline 2 & $4.73, b r s$ & $72.9 \mathrm{~d}$ & 4. $46, m$ & $73.0 \mathrm{~d}$ & $4.77, b r s$ & $72.9 \mathrm{~d}$ & $4.50, m$ & $72.9 \mathrm{~d}$ & 4.47, $m$ & $73.0 \mathrm{~d}$ \\
\hline 3 & $4.73, m$ & $73.2 \mathrm{~d}$ & $4.21, m$ & $79.9 \mathrm{~d}$ & $4.69, m$ & $73.2 \mathrm{~d}$ & $4.27, m$ & $78.8 \mathrm{~d}$ & $4.21, m$ & $79.9 \mathrm{~d}$ \\
\hline 4 & $4.36, m$ & $74.8 \mathrm{~d}$ & $4.53, m$ & $70.5 \mathrm{~d}$ & $4.33, m$ & $74.8 \mathrm{~d}$ & $4.52, m$ & $70.5 \mathrm{~d}$ & $4.53, m$ & $70.5 \mathrm{~d}$ \\
\hline 5 & $5.06, m$ & $70.0 \mathrm{~d}$ & $3.85, m$ & $78.1 \mathrm{~d}$ & $5.05, m$ & $70.0 \mathrm{~d}$ & $3.97, m$ & $78.6 \mathrm{~d}$ & $3.85, m$ & $78.1 \mathrm{~d}$ \\
\hline \multirow[t]{2}{*}{6} & $1.84, d(6.0)$ & $19.5 \mathrm{q}$ & $4.42,4.57, m$ & $62.4 \mathrm{t}$ & $1.82, d(5.6)$ & $19.4 \mathrm{q}$ & $\begin{array}{c}4.38, m \\
4.57, b r d(11.2)\end{array}$ & $62.4 \mathrm{t}$ & $4.34,4.55, m$ & $62.6 \mathrm{t}$ \\
\hline & & & \multicolumn{2}{|c|}{$\mathrm{R}$} & & & & & \multicolumn{2}{|c|}{$\mathrm{R}$} \\
\hline 1 & & & $6.44, b r s$ & $102.5 \mathrm{~d}$ & & & & & $6.40, b r s$ & $102.5 \mathrm{~d}$ \\
\hline 2 & & & $4.82, b r s$ & $73.3 \mathrm{~d}$ & & & & & $4.79, b r s$ & $73.3 \mathrm{~d}$ \\
\hline 3 & & & $4.77, m$ & $73.2 \mathrm{~d}$ & & & & & $4.76, m$ & $73.2 \mathrm{~d}$ \\
\hline 4 & & & $4.42, m$ & $74.8 \mathrm{~d}$ & & & & & $4.37, m$ & $74.9 \mathrm{~d}$ \\
\hline 5 & & & $5.08, m$ & $70.1 \mathrm{~d}$ & & & & & $5.06, m$ & $70.0 \mathrm{~d}$ \\
\hline 6 & & & $1.88, d(5.6)$ & $19.7 \mathrm{q}$ & & & & & $1.82, d(6.0)$ & $19.6 \mathrm{q}$ \\
\hline
\end{tabular}




\section{Table 3}

In vitro antitrypanosomal activities of triterpenoid saponins isolated from Mussaenda luteola against Trypanosoma brucei brucei.

\begin{tabular}{|c|c|c|c|}
\hline \multirow{2}{*}{ Compound } & \multicolumn{2}{|c|}{ Antitrypanosomal Activity } & THP1 cell Toxicity \\
\cline { 2 - 4 } & $\mathrm{IC}_{50} \mu \mathrm{g} / \mathrm{mL}(\mu \mathrm{M})$ & $\mathrm{IC}_{90} \mu \mathrm{g} / \mathrm{mL}(\mu \mathrm{M})$ & $\mathrm{IC}_{50}(\mu \mathrm{g} / \mathrm{mL})$ \\
\hline DFMO & $2.38(13.06) \pm 0.43$ & $5.28(28.99) \pm 0.24$ & $>10$ \\
\hline $\mathbf{1}$ & $9.13(8.80) \pm 0.64$ & $11.05(10.60) \pm 0.82$ & $>10$ \\
\hline $\mathbf{2}$ & $3.08(2.57) \pm 0.64$ & $4.27(3.56) \pm 1.12$ & $>10$ \\
\hline $\mathbf{3}$ & $2.75(2.61) \pm 0.09$ & $3.53(3.36) \pm 0.10$ & $>10$ \\
\hline $\mathbf{4}$ & $3.04(2.84) \pm 0.39$ & $4.64(4.35) \pm 1.70$ & $>10$ \\
\hline $\mathbf{5}$ & $>10$ & $>10$ & $>10$ \\
\hline
\end{tabular}

DFMO, Difluromethylornithine; $\mathrm{IC}_{50}$ and $\mathrm{IC}_{90}$ values are mean \pm S.D. of duplicate observations. $\mathrm{The} \mathrm{IC}_{50}$ and $\mathrm{IC}_{90}$ values were computed from dose-response curves presented in Fig. 3. The tested concentrations range $(0.4-10 \mu \mathrm{g} / \mathrm{mL})$. 

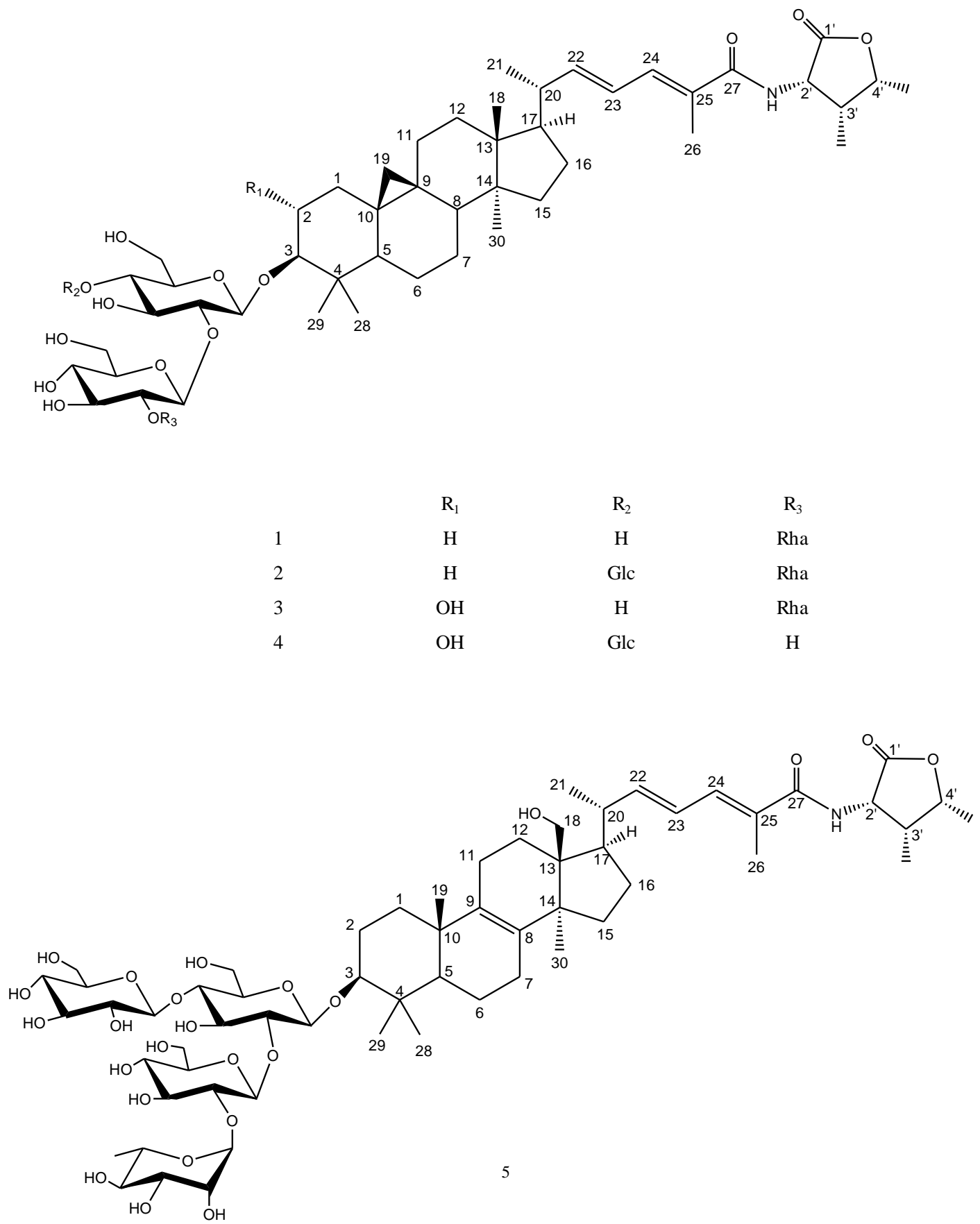

Fig. 1. Structures of isolated compounds 1-5 

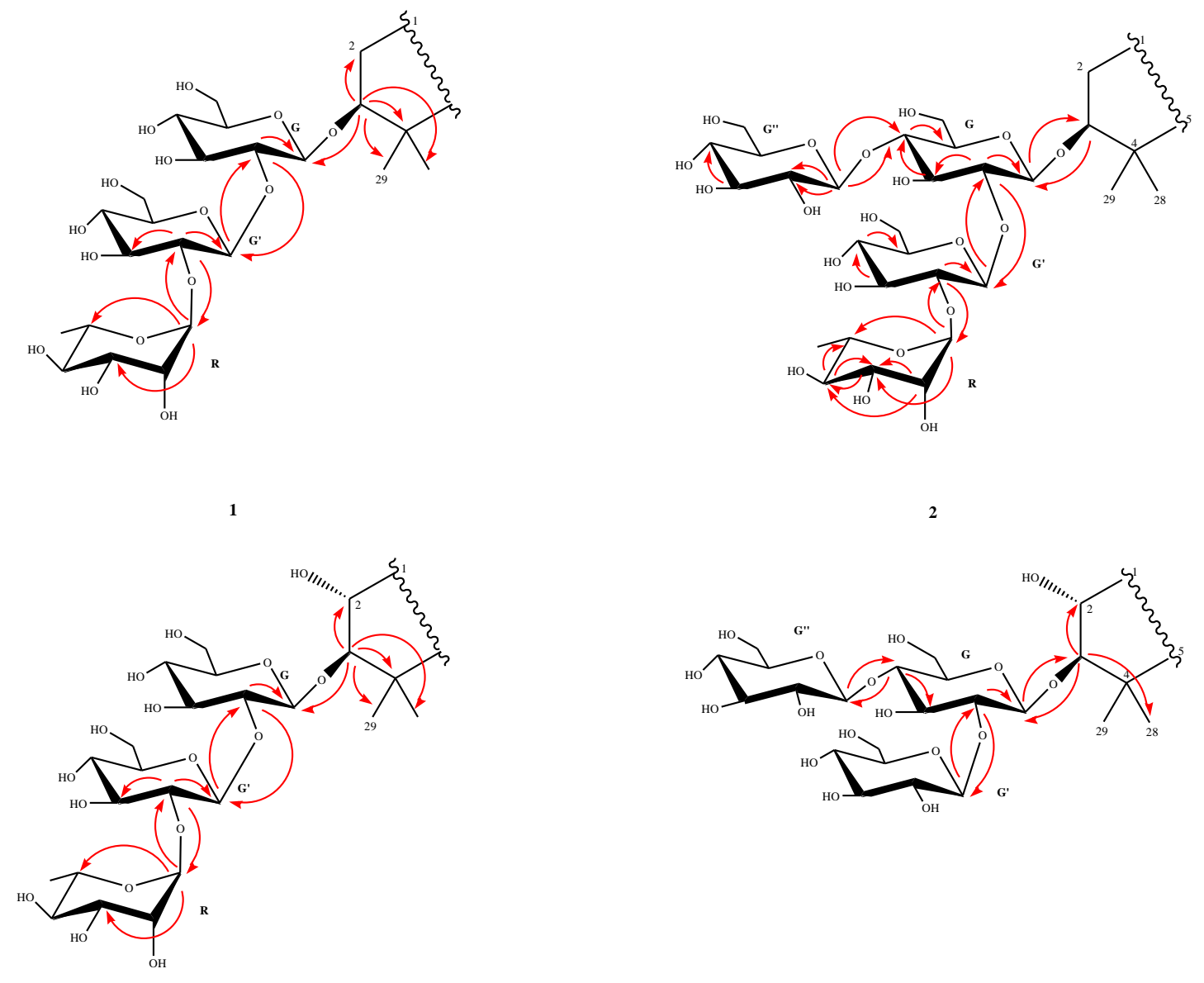

3

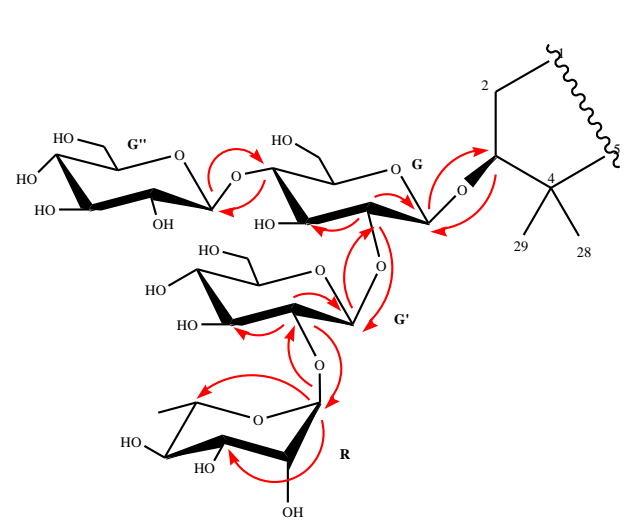

Fig. 2. Important $\mathrm{HMBC}(\mathrm{H} \rightarrow \mathrm{C})$ correlations among sugar units and aglycones of $\mathbf{1 - 5}$ 

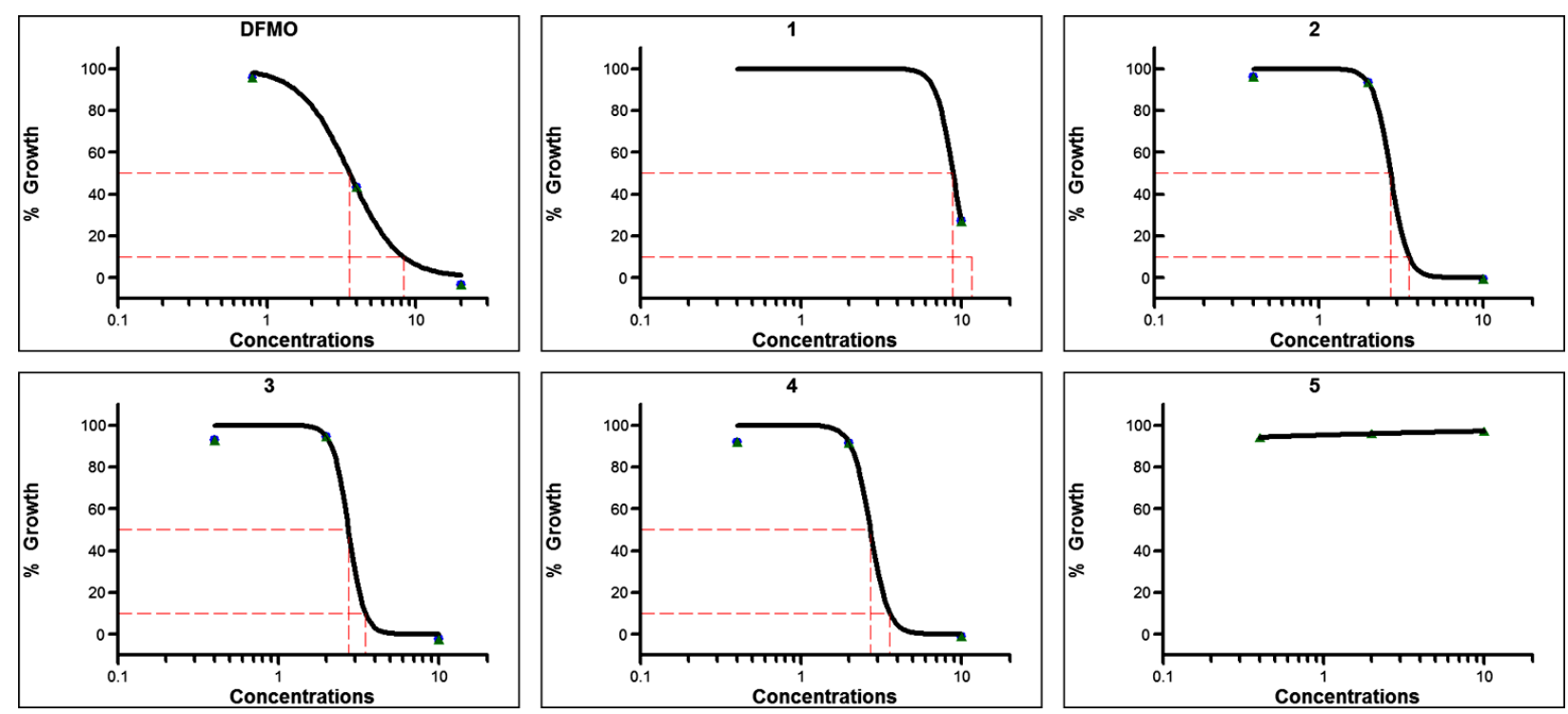

Fig. 3. In vitro antitrypanosomal activity of triterpenoid saponins (1-5) isolated from Mussaenda luteola against Trypanosoma brucei brucei. Difluromethylornithine, the clinically used antitrypansomal drug, was tested as a positive control. Each point represents values mean of duplicate observations. $\mathrm{IC}_{50}$ and $\mathrm{IC}_{90}(\mu \mathrm{g} / \mathrm{mL})$ values were computed with XLfit software. 


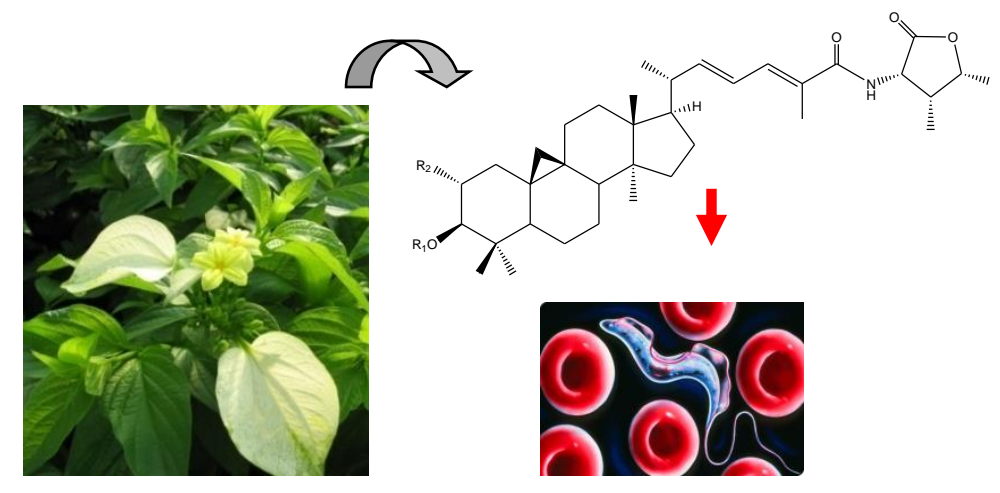

